\title{
Reversed Positions: Henry James, Realism, and Sexual Passion
}

\author{
By Raphaël Ingelbien
}

Recent work on James confirms that sexuality is a popular topic with contemporary critics, but the place of sexuality in James has long been one of the most disturbing and contentious aspects of his work. Early comments often insisted on what was perceived to be a damaging flaw in James's fiction. E. M. Forster observed that James's characters were "incapable . . . of carnality” and that "their clothes w[ould] not take off" (147). André Gide's objection was similar: for him, James's characters were "only winged busts; all the weight of the flesh is absent, and all the shaggy, tangled undergrowth, all the wild darkness" (258). Oscar Wilde, much as he liked the perversity of The Turn of the Screw, also feared that James would "never arrive at passion" (Gard 277). Biography has always been at hand to explain the absence lamented by Forster, Gide, and Wilde: James's New England Puritan background, personal inhibition, repressed homosexuality, or the nature of his famous "obscure hurt" can all be made to account for a lack of interest in human passions. Those early complaints also recall Charlotte Brontë's attack on Jane Austen, the old maid who looks like a perfect match for James's bachelor: Austen, Brontë wrote, ignored the human heart, "what throbs fast and full, though hidden, what the blood rushes through, what is the unseen seat of Life": "the Passions are perfectly unknown to her" (Wise and Symington 99).

One of James's few remarks on Austen interestingly provides an implicit reply to Brontë: "in of course an infinitely less explicit way, Emma Woodhouse and Anne Eliot [sic] give us as great an impression of 'passion'-that celebrated quality-as the ladies of G. Sand and Balzac" (SL 189). Passion, then, seems to be a disputed concept; capitals or quotation marks become ways of taking position in a literary debate. The same is true of "sexuality": James's condemnation of Hardy's Tess as "vile" is often taken to show his squeamishness in matters sexual, and yet James had added that in Hardy's novel "the pretense of 'sexuality' is only equaled by the absence of it" (LE 406). At stake here are the definitions 
of passion and sexuality, rather than their presence or absence. What really disturbs some readers is not James's neglect of sexuality, but his treatment of it. Conversely, what upsets James in writers like Zola is not that they make sexuality a central theme in their novels, but their approach to it: "it is not the choice of subject that has shocked us," James wrote of Nana, but Zola's treatment, which had "imparted . . . no touch of superior verity" to his protagonist (HF 280).

James's treatment of sexual passion is best analyzed as a strategic intervention in a literary and ideological debate. This is not to deny that biographical considerations can be relevant, but if the debate in question opposes writers like Austen and James to Brontë, Wilde, Gide, Forster, and Zola, it is not because Austen and James were probably denied first-hand experience of sex. The debate was actually about nothing less than the future of English realism and of the bourgeois subject of English fiction, at a time when they were being challenged by emerging literary modes which were represented by James's critics and adversaries. The aestheticism of Wilde, the naturalism of Zola, and a Nietzschean vitalism that exalted instinctual life and that was prefigured by Brontë (whose relation to Victorian realism was always problematic) was clearly present in Gide and sometimes surfaced in Forster's fiction. If one keeps in mind that those movements had a key role in the transition from realism to modernism, James's place in that transition will consequently have to be re-examined. Recent writing on sexuality in James has emphasized what it regards as an interest in deviant and marginal sexualities; this is then supposed to mark him off as a decadent or modernist artist who challenged the sexual norms inherited from Victorianism (see, for instance, Stevens). Those arguments are convincing up to a point, but they also end up relying heavily on biographical or psychoanalytical speculation about James's own sexual preferences. Considering his treatment of sexuality as part of a literary and ideological quarrel, on the other hand, not only offers a way out of psychobiographical dilemmas, but also provides an opportunity to reassess James's place in the shifts that English fiction underwent at the turn of the century. Indeed, such a focus suggests that James was mounting a calculated and strenuous defence of English realism against decadence, naturalism, and the rise of modernist definitions of subjectivity.

In his essay "The Future of the Novel” (1899), James admitted that English fiction was marked by "a mistrust of any but the most guarded treatment of the great relation between men and women," and that this was "an immense omission in our fiction" (HF 56). The phrase "our fiction" suggests that James regarded himself as perpetuating that English tradition. But if he himself often appeared to shun a "realistic" treatment of sex (in the common sense of the word), it was not primarily for biographical reasons or because he favoured a modernist aesthetics of indirectness. The reason was that he tried to deal with sexual passion in a way that would not threaten the ideology of English realism.

The "great relation" between man and woman is also central to James's 1902 essay on Gabriele D’Annunzio, the writer who James argues presents the "great relation, for intimacy, as we shall nowhere else find it presented" ( $F W$ 943). The essay on D'Annunzio is worth dwelling upon for several reasons. Although it has been relatively neglected by James critics, I will have many 
opportunities to show how its concerns and its very textual strategies can illuminate the fiction that James produced around the turn of the century. D'Annunzio is also an interesting figure in that he connects the different movements that threatened the ideology of English realism. D'Annunzio is a natural aesthete: "Beauty at any price is an old story to him; art and form and style as the aim of the superior life are a matter of course" (909); he is the "authentic . . specimen" of the "concrete esthetic "type" (908). His work also gestures towards naturalism: his characters are "creature[s] of organs, functions and processes, palpable, audible, pitiful physical conditions" (922), and his descriptions of human miseries are so full of Zola's "pictorial energy" that some French critics questioned D’Annunzio's originality (929). Finally, in his exaltation of “passion” (915) and of the will (volunta in Italian) at the expense of morality, D'Annunzio was an eminently Nietzschean novelist.

James concedes that D'Annunzio's emotional intensity shows up another limitation of English realism: "our English-speaking failure of insistence, of inquiry and penetration, in certain directions," a failure that sprang "partly from our deep-rooted habit of dealing with man, dramatically, on his social and gregarious side, as a being the variety of whose intercourse with his fellows . . . is positively half his interesting motion" (921). Ultimately, of course, James's sympathies are with the English novelist-Gide would after all complain that James's characters “never live except in relation to each other" (258). A strong sense of unease pervades James's essay on the Italian novelist; his main objection is that the "esthetic plenitude" (942) that D'Annunzio achieves through his focus on violent passion and extreme physicality is discredited by what it excludesnamely, any form of moral, social, and dramatic interest:

The sexual passion from which he extracts such admirable detached pictures insists on remaining for him only the act of a moment, beginning and ending in itself. ... Shut out from the rest of life, [sexual passion] has no more dignity than ... the boots and shoes that we see, in the corridors of promiscuous hotels, standing, often in double pairs, at the doors of rooms. (942)

Unlike the rest of James's essay, this passage has become widely known; its fame certainly owes much to Max Beerbohm's use of it in a caricature which showed a frowning James kneeling outside a door, his gaze fixed upon two pairs of shoesone male, one female (reproduced in Riewald 225). Beerbohm's humorous portrayal prefigured the later and more sinister denunciations of James as a mixture of fastidious Puritan and fascinated voyeur (see Geismar); it also helped fuel the kind of biographical speculation which has never been absent from James criticism. But Beerbohm's caricature, brilliant though it is, misrepresents James's intention-not only because, as Leon Edel argued, it wrongly conflates James with the voyeuristic narrator of The Sacred Fount (Riewald 224), but also because it misses the nature of James's critique of D'Annunzio. His problem is not that D'Annunzio deals straightforwardly with sexual passion, but that he fails to relate it to the "rest of life" (FW 942). The sentence that sheds most light on James's 
treatment of sexuality is actually the following: "What the participants do with their agitation, in short, or even what it does with them, that is the stuff of poetry" (943). The chiastic inversion of the subject-object relationship in that sentence shows that James was willing to let "passion" challenge his adherence to one of the key principles of English realism-namely, the belief in human subjectivity as a free agent in a social situation. When he somewhat grudgingly introduces the phrase "even what it does with them," James is on the verge of granting the point made by aesthetes, naturalists, and Nietzschean vitalists alike: that physical agitation-sexual passion-can become an active subject, both grammatically and existentially, and prove stronger than the psychological subject of English realism. Such chiastic inversions also recur in James's fiction, where they sometimes dramatize a similar tension between English realism and the heady mixture of aestheticism, naturalism, and vitalism represented by D'Annunzio. ${ }^{1}$ They enact a conflict between Jamesian consciousness and passions which threaten either to supplant that consciousness or to isolate it from the social and moral intrigues of English realism. Indeed, the other significant figure in James's sentence is the repetition of the verb "do," which insists on the importance of action in what constituted the paradoxical "poetry" of English realism for James.

The Wings of the Dove, which was written at the time when James was formulating his response to D'Annunzio, is arguably the best illustration of the generic ambiguity that defines James's later fiction. It can be described as either an English comedy of manners or an experiment in aestheticism, as either melodramatic or relentlessly introspective. In fact, it illustrates the very conflict between the definitions of subjectivity implied by these opposite genres. The thematic site on which that conflict is played out is that of sexuality. The crucial sexual encounter in the novel takes place off stage, when Densher and Kate consummate their passion for the first time, and is only conveyed through Densher's memories. On the face of it, this strategy could be seen as one of typical Jamesian indirectness or as yet another sign of some personal inhibition, of a piece with the earlier declaration that "in love, the names of things, the verbal terms of intercourse were, compared with love itself, horribly vulgar" (WD 250). But Densher's erotic memories are so obsessive that, to paraphrase the essay on D'Annunzio, it is not clear whether Densher does something with his agitation or if his agitation does something with him:

What had come to pass within his walls lingered there as an obsession to all his senses; it lived again, as a cluster of pleasant memories, at every hour and in every object; it made everything but itself irrelevant and tasteless. It remained, in a word, a conscious watchful presence; active on its own side, for ever to be reckoned with.... He had in fine judged his friend's pledge in advance as an inestimable value, and what he must now know for his case was that of a possession of the value to the full. Wasn't it perhaps even rather the value that possessed him, kept him thinking of it and waiting on it. . . ? (WD 415-16)

Densher's passion becomes an agent in its own right ("it lived," "it made," "it remained," "it remained" "active on its own side"); his absorption is such that he 
becomes similar to what James calls the “isolated erotomaniacs" of D'Annunzio's novels ( $F W$ 920). ${ }^{2}$ As if to stress that isolation, the chiastic inversion of subject and object positions in this passage no longer concerns a verb of action (i.e., "do" in the essay on D'Annunzio), but verbs which connote inaction and entrapment ("possess" and "keep"). However, Densher is not allowed to withdraw completely into his daydream, since that would cause James to bid farewell to English realism: "We fear to isolate [man], for we remember that as we see and know him he scarce understands himself save in action, action which inevitably mixes him with his kind" (FW 921-22). This is why Densher

tried to break by his own act his constant still communion. It wasn't still communion [Kate] had meant to bequeath him, it was the very different business of that kind of fidelity of which the name was careful action.

Nothing, he perfectly knew, was less like careful action than the immersion he enjoyed at home.... He had to remember it was time to go to the palace. (417)

Densher's example shows that the Jamesian consciousness can at times be overwhelmed by sexual passion. But passion for James involves more than sex itself. Indeed, another similar chiastic inversion also dominates the opening of "The Altar of the Dead," where sexual fulfillment is forever denied: "Again and again [Stransom] had kept in his own fashion the day of the year on which [his fiancée] Mary Antrim had died. It would be more to the point perhaps to say that the day kept him: it kept him at least, effectually, from doing anything else" (CT 231). As in The Wings of the Dove, the inversion affects the subjects and objects of the verb "keep," which separates Stransom from the world of social action. Stransom's devotion to his dead fiancée becomes an "immense escape from the actual" (232): that is why his case is not the subject of a Jamesian novel, but of one of James's most phantasmagoric tales. Although we may be tempted to analyze the story in biographical terms (Gordon 294-96), "Altar" can also be read as a subtle critique of the aestheticist detachment from reality. ${ }^{3}$ Stransom is actually an inverted erotomaniac: his isolation from the "rest of life" is the result of a self-imposed mortification which is as absorbing as the sexual passions of D’Annunzio's novels. Stransom's example can also help us understand Densher's transformation at the end of The Wings of the Dove: Densher becomes obsessed with the woman he will never have loved (Milly), and he lapses into the same dreamy inertia that was caused by his erotic memories. Milly's posthumous influence becomes "a faint far wail," "the sound he cherished when alone in the stillness of his rooms. He sought and guarded the stillness, so that it might prevail there till the inevitable sounds of life, once more, comparatively coarse and harsh, should smother and deaden it" (503). Densher's sexual passion for Kate is exchanged for his growing obsession with the dead Milly: in some readings, this substitution is seen as a proof of James's dismissal of sexuality and of his preference for renunciation. But this disregards the possibility that James may once 
again be criticizing aestheticist detachment through his portrayal of Densher. Such an analysis is borne out by the fact that both Densher and Stransom find psychological support in Catholic rituals, whose appeal to fin-de-siècle decadents is well documented. The church where Stransom worships at the altar of his memories is a "temple of the old persuasion" where "the high altar was still a blaze of candles” (CT 238). After he has heard of Milly's death, Densher chooses to attend the Christmas service at the Catholic Brompton Oratory, where he is met by "the blaze of altar lights and the swell of organ and choir. It didn't match his own day, but it was much less of a discord than some other things actual and possible. The Oratory in short, to make him right, would do" (WD 507). James's descriptions bring out the isolation and the aesthetic solace afforded by Catholicism, which thus functions primarily as a marker of the aestheticism that he associates with D'Annunzio. ${ }^{4}$

Another problem with readings that stress James's own attraction to detachment and renunciation is that they also rely on a narrow definition of sexuality. Shoshana Felman has reminded us that for Freud sexuality was more than the fulfillment of physical longings: "In psychoanalysis the concept of what is sexual comprises far more, it goes lower and higher than in its popular sense" (Freud, qtd. in Felman 109). In other words, repression, sublimation, and lack of satisfaction are as constitutive of the Freudian definition of sexuality as are desire and fulfillment. James's insistence on a complex approach to a polymorphous "sexuality" is Freudian in the proper sense of the term, not in the vulgar sense which makes "Freudian” critics focus on phallic symbols in James's work. Indeed, James was out to rescue the psychological subject of English realism from physiological determinism; his treatment of sexual passion was as much intended to keep naturalism and primitivism at bay by reasserting the primacy of psychology and consciousness as it was designed to resist the aesthetic temptation which would isolate that consciousness from social interaction. Aestheticism being a largely masculine or even homoerotic phenomenon, the dangers of aesthetic and decadent passion are explored through male characters like Stransom and Densher, who sometimes succumb to aestheticism. Physiological determinism, on the other hand, is warded off by James's female protagonists. The most central Jamesian consciousness is generally female-in this, too, James followed the major exponents of English psychological realism from Austen onwards. Zola's depiction of such a female subject as "a brutal fille, without a conscience or a soul, with nothing but devouring appetites and impudences," offended James. But the offence was at least as much against the ideology of English realist fiction as against James's supposedly old-maidish Puritanism-James, after all, chose that opportunity to claim that English novelists were "by disposition the better psychologists" (HF 280). In The Golden Bowl (arguably one of the last great products of English realism), James's female heroine Maggie Verver is the one who reverses the chiastic inversion of the essay on D'Annunzio in order to let human consciousness triumph.

David McWhirter writes that The Golden Bowl is unusual in that James's last great novel "is also his first to end in the achievement of love" (142). McWhirter distinguishes between desire and love, which is "not a mode of 
consciousness or imagination, but action" (6). Indeed action-as defined in the essay on D'Annunzio-is what saves Maggie and justifies Gabriel Pearson's description of The Golden Bowl as "an epic of selfhood achieved and disengaged from [the] raw coercions of carnality" (323). For Pearson, physiological constraints are essentially a naturalist theme; in this novel, however, they are also associated with decadence and vitalism. They are significantly represented by Amerigo-an Italian prince of Catholic religion and pagan inclinations, who would not have been out of place in D'Annunzio's fiction or, later, in Forster's $A$ Room with a View (1908). But as the binary structure of the novel indicates, "The Prince" must eventually make way for "The Princess," as Maggie actively disengages herself from his spell and forces him to accept the terms in which she defines their marriage. This reversal is notably dramatized in the following passage, where Prince Amerigo has put his arm round Maggie's waist:

she was in his exerted grasp, and she knew what that was; but at the same time she was in the grasp of her conceived responsibility, and ... of the two intensities, the second was presently to become the sharper. ... [The Prince] had resorted to unfailing magic. He knew how to resort to it-he could be, on occasion, as she had lately more than ever learned, so munificent a lover. ... She should have but to lay her head back on his shoulder with a certain movement to make it definite for him that she didn't resist. To this, as they went, every throb of her consciousness prompted her-every throb, that is, but one, the throb of her deeper need to know where she "really" was. By the time she had uttered the rest of her idea, therefore, she was still keeping her head and intending to keep it. ... (GB 375-76)

Maggie's "responsibility" is not only to her sense that her marriage must be purified of the affair that her husband is having with Charlotte, but it also extends to the conventions of English realism and to the bourgeois consciousness that was central to James's fiction. In The Portrait of a Lady, the task had been entrusted to Isabel Archer, who prefigures Maggie in this respect as in many others. Caspar Goodwood's kiss in the final scene

was like lightning ... [Isabel] felt each thing in his hard manhood that had least pleased her, each aggressive fact of his face, his figure, his presence, justified of its intense identity and made one with its act of possession. So she had heard of those wrecked and under water following a train of images before they sink. But when darkness returned she was free. (625)

Once again, this equation of freedom with sensual deprivation has often come to be regarded as typically Jamesian. But the similarities between The Portrait of a Lady and The Golden Bowl show the problem of that interpretation. Maggie's resistance is somewhat similar to Isabel's-in the following scene, James's imagery recalls the one used in the scene between Caspar Goodwood and Isabel Archer. The Prince 
was so near now that she could touch him, taste him, smell him, kiss him, hold him; he almost pressed upon her, and the warmth of his face ... was bent upon her with the largeness with which objects loom in dreams. ... Then it was that, from behind her closed eyes, the right word came. "Wait!" It was the word of his own distress and entreaty, the word for both of them, all they had left, their plank now on the great sea ... he let her go ... she had saved herself and she got off. (GB 391-92)

In The Golden Bowl, however, Maggie's resistance does not imply renunciation; eventually, it will help her reconcile the sexual fulfillment she has found in her marriage with the social and moral significance of that marriage-what James called the "rest of life" in the essay on D'Annunzio. In other words, Maggie performs thematically what the novel tries to perform structurally: to reconcile sexual passion with the conventions of English realism.

Novels like The Wings of the Dove and The Golden Bowl have long been discussed as modernist departures from realist fiction-not only because of their formal and psychological sophistication, but also because of their treatment of sexual themes. Tony Tanner explicitly links these different aspects in Adultery and the Novel, where he suggests that the later James's focus on adultery and his challenge to "bourgeois reading expectations" meant that he had "ceased to write bourgeois novels" (99). Instead, James's later fiction is supposed to belong to what Tanner calls "postsocial fictional forms involving extreme states of physicality and linguicity (or Proustian solipsism)" (14). My aim has been to show that James's treatment of sexuality and some of his most elaborate formal strategies cannot quite be regarded as modernist or aestheticist subversions of realism. When analyzed in the light of James's critical pronouncements (notably those of the neglected essay on D'Annunzio), they actually turn out to dramatize his attempt at making sexual passion possible for the bourgeois novel, while avoiding the dangers of decadent solipsism and of the naturalist or Nietzschean emphasis on physicality. They are as it were textual and narrative defense mechanisms against threats posed to the literary representation of bourgeois consciousness at the turn of the century, and they reveal a more traditional James than is often suggested. The transition from realism to modernism was of course an extremely complex and multi-faceted process, and terms like "realism," "aestheticism" and "modernism" remain slippery. The difficulty of James's late style, his epistemological concerns and his influence on modernists like Eliot and Pound will always tend to align him with the last two. ${ }^{5}$ But if those terms are taken to designate literary forms that carry different ideologies of subjectivity, then James's treatment of sexual passion shows that he was the most self-conscious representative of the English realist novel, which he tried to arm against the attacks of early modernism. 
NOTES

${ }^{1}$ Chiastic inversion is of course one of James's favorite rhetorical figures (see Norrman's chapter "Chiastic Inversion, Antithesis and Oxymoron" [137-85], but the specific cases I will be analyzing all foreground the role of sexuality in his fiction.

2One of D'Annunzio's novels is set in "the autumn light of Venice" (FW 920), and Densher and Kate's encounter takes place in Venice at the beginning of autumn (WD 431).

${ }^{3}$ Those two readings need not be exclusive: James may very well have been criticizing his own aestheticizing tendencies.

${ }^{4}$ Although D'Annunzio was a self-styled pagan, his Latinity no doubt reinforced a possible connection to Catholicism.

${ }^{5}$ However, Freedman has shown that the modernist appropriation of James had to play down some of the more traditionalist aspects of his work (245-57) and that his relation to aestheticism was sometimes quite critical.

\section{WORKS BY HENRY JAMES}

CT-The Complete Tales of Henry James. Ed. Leon Edel. Vol. 9. London: Hart-Davis, 1964.

FW-French Writers, Other European Writers, the Prefaces to the New York Edition. Ed. Leon Edel. New York: Library of America, 1984. Vol. 2 of Literary Criticism.

GB-The Golden Bowl. London: Bodley Head, 1971.

HF-The House of Fiction. Ed. Leon Edel. London: Hart-Davis, 1957.

LE-The Letters of Henry James. Ed. Leon Edel. Vol. 3. London: Macmillan, 1980.

The Portrait of a Lady. London: Bodley Head, 1968.

SL-Selected Letters. Ed. Leon Edel. Harvard: Belknap, 1974.

WD-The Wings of the Dove. London: Bodley Head, 1969.

\section{OTHER WORKS CITED}

Felman, Shoshana. "Turning the Screw of Interpretation.” Yale French Studies 55/56 (1977): 94207.

Forster, E. M. Aspects of the Novel. London: Arnold, 1949.

Freedman, Jonathan. Professions of Taste: Henry James, British Aestheticism and Commodity Culture. Stanford: Stanford UP, 1990.

Gard, Roger, ed. Henry James: The Critical Heritage. London: Routledge, 1976.

Geismar, Maxwell. Henry James and His Cult. London: Chatto, 1964.

Gide, André. "Henry James." The Question of Henry James. Ed. F. W. Dupee. London: Wingate, 1947. 256-63.

Gordon, Lyndall. A Private Life of Henry James: Two Women and His Art. London: Chatto, 1998. McWhirter, David. Desire and Love in Henry James. Cambridge: Cambridge UP, 1989.

Norrman, Ralf. The Insecure World of Henry James's Fiction. London: Macmillan, 1982.

Pearson, Gabriel. "The Novel to End All Novels: The Golden Bowl." The Air of Reality. Ed. J. A. Goode. London: Methuen, 1972. 301-62.

Riewald, J. G., ed. Beerbohm's Literary Caricatures from Homer to Huxley. London: Lane, 1977. Stevens, Hugh. Henry James and Sexuality. Cambridge: Cambridge UP, 1998.

Tanner, Tony. Adultery in the Novel. Baltimore: Johns Hopkins UP, 1979.

Wise, T. J., and J. A. Symington, eds. The Brontës. Their Lives, Friendships and Correspondence. Vol. 3. Oxford: Blackwell, 1980. 